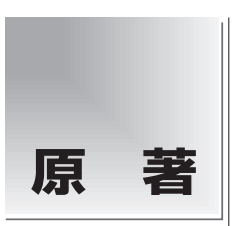

2010 年 7 月9 9 論文受付
2011 年 1 論文受理
Code Nos. 254
522

\section{肺腺癌ファントムを用いたソフトコピー(LCD)と ハードコピー(Film)の病変検出能の比較}

\author{
望月安雄 $^{1)}$ ・ 阿部慎司 ${ }^{2)} \cdot$ 門間正彦 $^{2)}$ ・ 山口弘次郎 ${ }^{3)} \cdot$ 安達登志樹 ${ }^{4)}$
}

\section{緒 言}

画像検查に用いられる各種モダリティのディジ夕 ル化やネットワークの進展に伴い, 画像診断のディ スプレイは，著しい技術の進歩によってブラウン管 ディスプレイ(cathode ray tube: CRT)と液晶ディスプ レイ(liquid crystal display: LCD)の視覚評価で検出能 に差1,2)がないことから，観察環境や省スペース化に 優れている LCDに置き代わりつつある.

これまで臨床画像をハードコピーとソフトコピーで 観察し，両者の性能を receiver operating characteris-
1 ) 日本医療科学大学

2) 茨城県立医療大学

3) 藤田保健衛生大学

4) 福井大学医学部附属病院

\title{
Comparison of Detectability of Liquid Crystal Displays (LCDs) and Film Using Phantoms of Small Adenocarcinomas as Abnormalities
}

\author{
Yasuo Mochizuki, ${ }^{1)}$ Shinji Abe, ${ }^{2)}$ Masahiko Monma, ${ }^{2)}$ Kojirou Yamaguchi, ${ }^{3)}$ and \\ Toshiki Adachi ${ }^{4}$ \\ 1) Nihon Institute of Medical Science \\ 2) Ibaraki Prefectural University of Health Sciences \\ 3) Fujita Health University of Health Sciences \\ 4) University of Fukui Hospital \\ Received July 9, 2010; Revision accepted January 17, 2011; Code Nos. 254, 522
}

\section{Summary}

Following the trend of the digitalization of the modalities used for diagnostic imaging, the devices for such imaging have increasingly included monitors. The present study was undertaken to evaluate the usefulness of soft-copy (liquid crystal display; LCD) images of phantoms of small adenocarcinomas using receiver operating characteristic (ROC) analysis of two different display systems: LCD and hard copy (film). A twotailed paired $t$-test and the jackknife method (parametric methods) were performed, and no significant differences were found in the area under the ROC curve (AUC) for the pulmonary fields, lungs, ribs, or mediastinum between the film and LCD display systems, and the detectability did not differ between the film and LCD monitors. A Mann-Whitney $U$ test, which is a non-parametric method that applies to the analysis of a small sample, also showed no significant differences in the AUC. The results of this study suggest that LCDs can replace hard-copy film as a display system if the signals.

Key words: liquid crystal display (LCD), small adenocarcinoma, jackknife method, Mann-Whitney U test, receiver operating characteristic (ROC) analysis 
はなされていなかった。

本研究では, 肺野部・肋骨部および縦隔部と X 線 吸収が同等なアクリル板で作成した胸部模擬ブロッ クファントム (以下, 胸部模擬ファントム)に小野ら ${ }^{6)}$ が開発した京都科学社製の肺腺癌ファントムを置い て観察試料を作成した。 このファントムは, タイプ別 に肺腺癌の X 線吸収 ( CT 值)をもとに形状を変えて 作成されているので, 胸部肺腺癌の探索等の基礎的 な観察実験に適している.

その X 線画像をレーザーイメージャ(ドライ方式) でハードコピーした画像(以下, Film 画像)と digital imaging and communication in medicine(DICOM) Viewer を用いLCD で観察するソフトコピー(以下, LCD 画像)とで ROC 曲線下面積 (area under the ROC curve: AUC)によって検出能を求め, LCD の病変検出 の有用性について統計的有意差検定を行い, LCDの 有用性について検討した。

AUC 平均值の有意差検定は，正規分布を仮定する パラメトリック法の両側 paired t-検定と Jackknife 法 で行った. 平均值検定は分布の正規性や分散につい て厳しい条件があるため, ROC 解析の評定実験で得 られたすべての連読確信度について正規性を調べた。 さらに，信号に用いた肺腺癌ファントム画像の試料数 が少なかったため, 補足的にデー夕群の分布が分から ないときに用いるノンパラメトリック法の Mann-Whitney の $U$ 検定 $^{7)}$ でも有意差の判定を行った。

\section{1. 実験方法}

\section{1-1 観察試料の作成}

\section{1-1-1＼cjkstart肺腺癌ファントムの選定}

ROC 解析の観察試料に用いた肺腺癌ファントムの 材質は, 均一密度で人体軟組織に近い夕フウォー夕 (密度 : $1.01 \mathrm{~g} / \mathrm{cm}^{3}$ ) で作成されている. そのX 線吸収 が径や形状によって異なる 13 種類 $(20 \mathrm{~mm}$ を除く)の 肺腺癌ファントムを用いた。

評定は，視覚評価実験の経験がある 8 名の学生 で，無作為に1)病変がある，2）病変があると思う， 3)判らない, 4)病変はないと思う, 5)病変はないの 5 段階評価法で行った。観察試料は, 病変があると評 価した割合6) が 35〜 70\%程度の難易度の異なる5 種 類を選定した(Fig. 1). 選ばれた肺腺癌ファントム径 は, $7.0 \mathrm{~mm}$ が 3 個, $10.0 \mathrm{~mm}$ と $15.0 \mathrm{~mm}$ が各 1 個で あった

\section{1-1-2 胸部模擬ファントムの作成}

増感紙一フィルム系 $(\mathrm{SPO} 250 / \mathrm{SR} \mathrm{G}$ : コニカミノル 夕社製)で胸部ファントム PBU-X 21 (京都科学社製) を用いて撮影した画像上で, 肺野部・肋骨部・縦隔部 の写真濃度 ${ }^{8,9)}$ が適切になるように撮影条件を決め

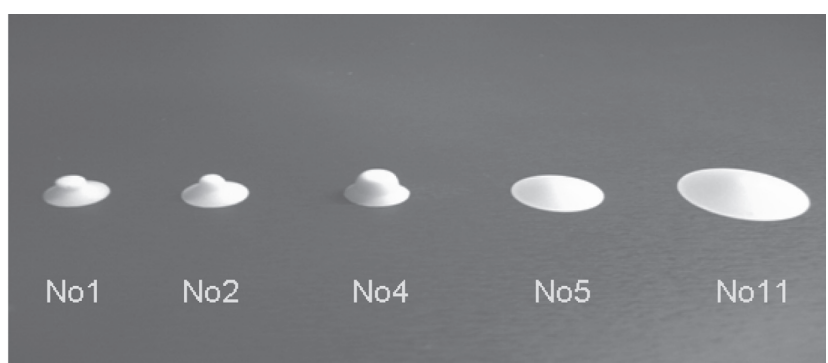

Fig. 1 Phantoms of small adenocarcinomas ${ }^{6}$ used for observation experiment.

Phantom No. 1; diameter: $7 \mathrm{~mm}$, area of core: $15 \%$, CT value of core: $-50 \mathrm{HU}, \mathrm{CT}$ value on the circle with radius $\mathrm{fR}:-300 \mathrm{HU}, \mathrm{CT}$ value on the circle with radius $\mathrm{R}:-750 \mathrm{HU}$ (type $\mathrm{B}$ ).

Phantom No. 2; diameter: $7 \mathrm{~mm}$, area of core: $15 \%$, CT value of core: $50 \mathrm{HU}, \mathrm{CT}$ value on the circle with radius $\mathrm{fR}:-300 \mathrm{HU}, \mathrm{CT}$ value on the circle with radius $\mathrm{R}$ : $-750 \mathrm{HU}$ (type $\mathrm{B}$ ).

Phantom No. 4; diameter: $7 \mathrm{~mm}$, area of core: $40 \%$, CT value of core: $-50 \mathrm{HU}, \mathrm{CT}$ value on the circle with radius $\mathrm{fR}:-300 \mathrm{HU}, \mathrm{CT}$ value on the circle with radius $\mathrm{R}$ : $-750 \mathrm{HU}$ (type $\mathrm{C}$ ).

Phantom No. 5; diameter: $10 \mathrm{~mm}$, CT value on the circle with radius $f R:-300 \mathrm{HU}, \mathrm{CT}$ value on the circle with radius $\mathrm{R}:-750 \mathrm{HU}$ (type $\mathrm{A}$ ).

Phantom No. 11; diameter: $15 \mathrm{~mm}$, CT value on the circle with radius $\mathrm{fR}$ : $-300 \mathrm{HU}$, CT value on the circle with radius $\mathrm{R}:-750 \mathrm{HU}$ (type A).

た.その結果，焦点ーカセッテ間距離 $200 \mathrm{~cm}$, 管電 圧 $120 \mathrm{kV}$, 管電流 $200 \mathrm{~mA}$, 撮影時間 0.04 秒であっ た.なお, 散乱 $\mathrm{X}$ 線の除去は, 移動型のアルミグ リッド(格子比 $10 ： 1$ ，グリッド密度 40 本 / cm) を使用 した。自動現像機は，コニカミノルタ製の SRX-503 を用い，臨床で一般的に使用している現像時間を 90 秒，現像温度を $33.5{ }^{\circ} \mathrm{C}$ に設定して処理を行った。

胸部模擬ファントムは，前述の撮影条件で，増感 紙ーフィルム系の画像上での写真濃度と同じになるよ うにアクリルファントム厚を変化させて, 胸部 X 線写 真における肺野部と胁骨部および縦隔部を模擬して 作成した。

胸部を模擬したアクリルファントム厚は，肺野部で $4.0 \mathrm{~cm}$ (濃度約 1.75), 縦隔部で $10 \mathrm{~cm}$ (濃度約 0.45 ), 肋骨部では厚さ $4.0 \mathrm{~cm}$ のアクリルファントムにアルミ ニウム板 $2.0 \mathrm{~cm}^{10)}$ を加えることで同等な濃度(濃度約 1.15)が得られた。

\section{1-2 ROC 解析の試料と観察実験}

Film 画像と LCD 画像の観察試料は，輝尽性蛍光 体プレートを用い，増感紙ーフィルム系での胸部ファ ントム撮影と同じ幾何学条件で, 胸部模擬ファントム と肺腺癌ファントムを撮影して取得した。

CR 装置 (Regius Model 170)の階調曲線は, look up table から胸部用モードとしてメーカが推奖している 


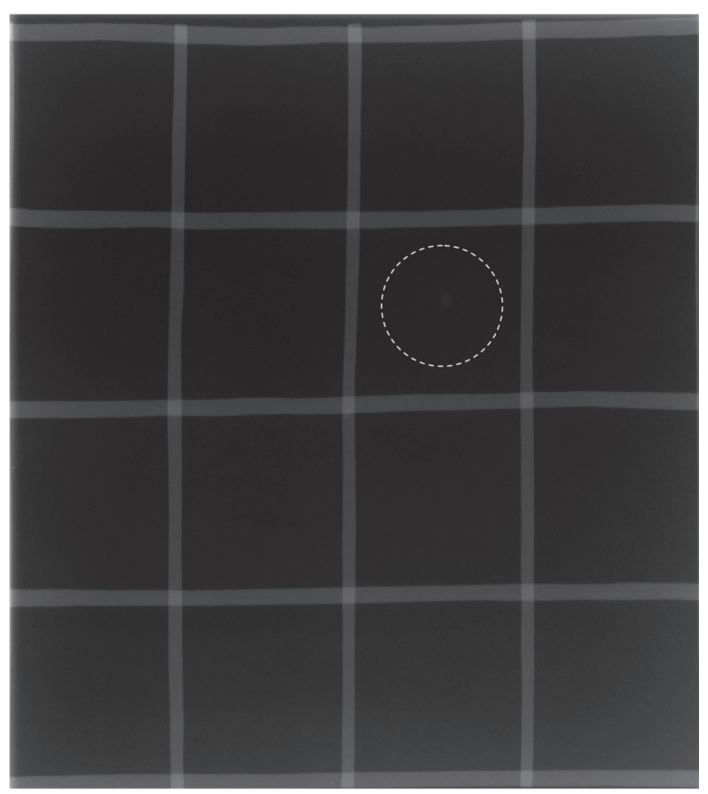

Fig. 2 The 16 divisions used for observation. An adenocarcinoma is shown in the circle.

THX-01 ( $\mathrm{G}$ 值；1.81)を選択し, 周波数処理などは行 わずに標準画素サイズ $(\mathrm{ST}: 0.175 \mathrm{~mm})$ の画像を出力 した.

ROC 解析の試料は, 厚み $0.1 \mathrm{~mm}$ の 4 切サイズの 銅版に 60×90 mm の格子を 16 個穿孔して 1 枚の画像 を16等分に分割 ${ }^{11)}$ した。

観察試料は，分割した 16 孔の任意の箇所に難易度 の異なる 5 種の肺腺癌ファントムをおのおの 3 回ラン ダムに使用し，胸部模擬ファントム + 肺腺癌ファント ムを信号像とする 15 画像，胸部模擬ファントムのみに よる雑音像の 15 画像の計 30 画像で 1 セットとした.

観察実験は，肺野部・肋骨部・縦隔部で各 1 セット 作成した総計で 90 画像を用いた。Fig. 2 に観察に用 いた画像の 1 例を示す.

画像の読影は, 十分にトレーニングした学生 8 名 で行った。観察者には事前の注意として，正面視で 上下や左右など周囲の 16 孔との比較をしないことを 依頼した。観察距離と観察時間は各観察者で任意と し，特に制限をしないで順番通り観察を進めた。ま た，学習効果の影響を考慮し，試料の観察は観察者 ごとで順番を換えた。さらに，Film 画像と LCD 画像 の観察は 10 日程度の間隔を空け，観察者の半数 4 名 で交互に観察を行い，読み取り順序効果の影響にも 配慮した。確信度は 50 点満点の連続確信度法でレー ティングを行った。

\section{1-3 観察の条件}

Film 画像の読影環境は，通常業務下の明室状態を 照度計(コニカミノルタ社製：T-1)で計り約 $2001 \mathrm{x}$,

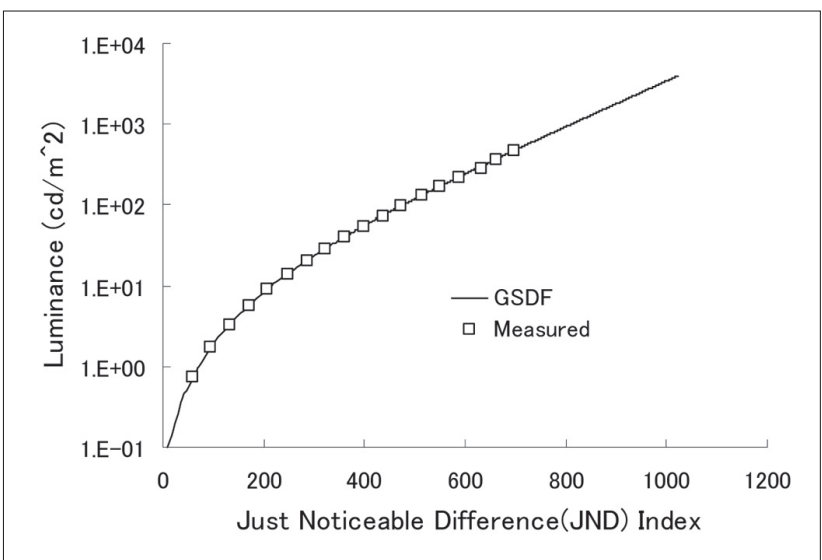

Fig. 3 Grayscale standard display function (GSDF) and measured characteristic curve for liquid crystal display (LCD).

シャウカステン(森山 X 線用品社製：CH5K)の照度 は，パネル前面から $20 \mathrm{~cm}$ の位置で約 4800 lx であった.

LCD の観察条件は，LCD 表面への外光の影響が ない角度に配置し, 一般的に臨床現場の読影環境で 影響がないといわれている2,12)，LCD 表面で約 $501 x$ に室内光を調整した。

LCD は, EIZO 社製の $3 \mathrm{M}$ pixels のモノクロ液晶 モニタ (Radi-Force G31-S : 画素ピッチ 0.207×0.207 $\mathrm{mm}$ ，コントラスト比 $900: 1$, 最大輝度 $\left.700 \mathrm{~cd} / \mathrm{m}^{2}\right)$ を 用いた。実際の LCD の輝度範囲は，最小輝度は 0.73 $\mathrm{cd} / \mathrm{m}^{2}$, 最大輝度はメーカ推奨の $450 \mathrm{~cd} / \mathrm{m}^{2}$ で行った.

CR 装置の画素サイズ (ST)で取得したDICOM 画 像は，バイオアーツ社製のBio DC-Viewerを用い, Viewerソフトでウインドウ幅を 2047，ウインドウレ ベルを4096のCR 装置のデフォルト值に固定し, LCD 画面 $(318 \times 424 \mathrm{~mm})$ へ最大に表示した

LCDの表示階調特性は, American Association Physicists Medicine Task Group 18(AAPM-TG18)の 18 パターンの濃度を TOPCON 社製の輝度計(BM-8) で計り，DICOM Part14に準拠する Grayscale standard display function $(\mathrm{GSDF})^{13)}$ とコントラスト応答 ${ }^{14)}$ を表計算ソフト(Microsoft Excel 2003)で求めた(Fig. $3,4)$.

コントラスト応答は, 平均值 $\pm 1 \%$ の誤差範囲で キャリブレーションされている。また，実験を開始す る前に JESRA X - 0093 医用画像表示用モニタの品 質管理に関するガイドラインに対応した受入試験を 実施し，読影モニタが基準を満たしていることを確認 した。

\section{1-4 AUC の有意差検定}

Film 画像と LCD 画像の平均值検定は, ROC 解析 で検出能の指標である AUCを用いて, 観察者間や 
試料間で生じる変動の影響を除いて検定ができる Jackknife 法と観察者間変動で評価する両側 paired t-検 定で行った。

Jackknife 法による統計的有意差検定は連続確信度 法による LABMRMC ${ }^{5)}$ (DBM 法：D. D. Dorfman, K. S. Berbaum, アイオワ大学, C. E. Metz, シカゴ大学) を用いて行った。なお，観察者は評価に使用したソ フトウェア(LABMRMC)の制約内の 8 名で行った.

今回は観察試料が少なかったため, ノンパラメト リック法の Mann-Whitneyの $U$ 検定でも有意差の判 定を行った。独立した 2 標本で検定できるMannWhitneyは，対応するデータのときに用いられる Wilcoxon signed-rank 検定よりも沉用性が広く結果も 同じになるために, Mann-Whitney-Wilcoxson 検定と して広くノンパラメトリックの検定に用いられている.

以上の各検定の統計的有意差は, $\mathrm{P}<0.05$ で有意差 ありと判定した。

\section{2. 測定結果}

\section{2-1＼cjkstart連読確信度の正規性について}

肺野部・肋骨部・縦隔部の杂隹音像と信号像から得ら れた連読確信度 (96 個)を用い，階級等を一律で計算 した度数分布は，単峰性が約 $88.5 \%$ ，一様性が約 $11.5 \%$ で, $\chi^{2}$ の正規性の適合度検定ではすべて不適 合だった。

次に，正規性の検定としてデー夕数が 20 以下のと きに用いる素分布検定の結果は, Film 画像は雑音で 7 と信号で 2, LCD 画像は雑音と信号がともに 2 の 全体で約 $15 \%$ において正規性が裹却された。棄却さ れたデー夕は，雑音像の連読確信度での度数のピー ク值が約 11 以下, 信号像の連読確信度でのピーク值 が約 39 以上とともに，信号なし側と信号あり側へと 偏りがみられた。

正規分布の適合度検定で不適合とされた単峰性 (88.5\%) と素分布検定で棄却されず正規性が保留さ れた $85 \%$ でよい対応がみられた。よって，観察者ご との雑音像と信号像の連読確信度が各 15 と少なかっ たため，観察試料の正規性は脆弱であった。

\section{2-2 ROC 曲線の AUC と検定結果}

観察者 8 名によるアベレージ法で求めた Film 画像 と LCD 画像に関する ROC 曲線を Fig. 5 に示す。

肺野部での ROC 曲線下面積の AUC の差は, 約 0.05 とわずかに LCD 画像の検出能が高い值を示した (Fig. 5a). 肋骨部での AUCの差は, Film 画像と LCD 画像で約 0.001 と拮抗し, 観察者の支持も半数 ずつに分かれた。縦隔部でのAUCの差は, Film 画 像と LCD 画像で約 0.008 と肋骨部と同様に差は微少

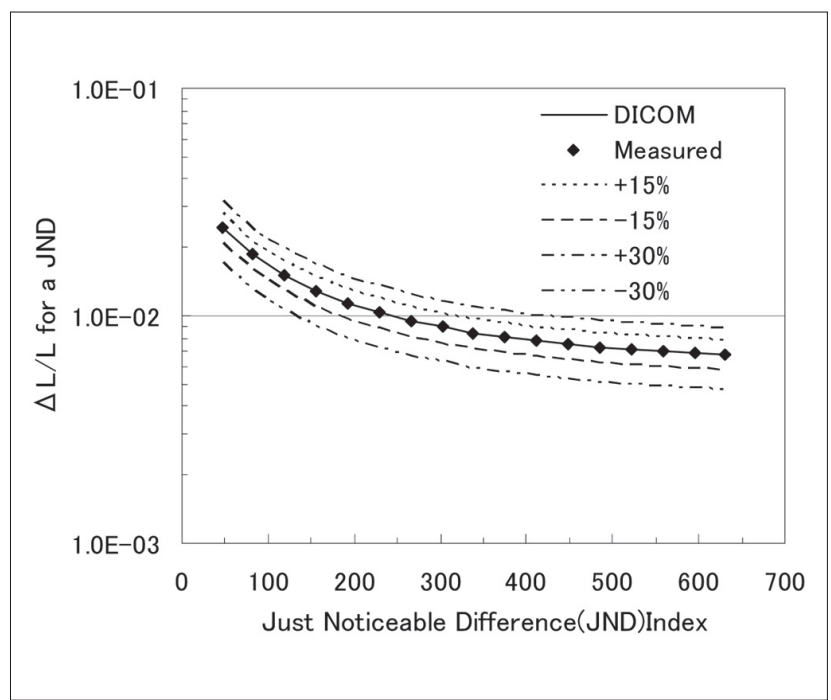

Fig. 4 Relationship between contrast response of measured characteristic curve and GSDF.

だった。

肺野部・肋骨部・縦隔部の Film 画像と LCD 画像 の両側 paired t-検定で, 有意水準 0.05 で検定した結果 を示す(Table 1)。両者で有意差は認められなかった。

Jackknife 法による肺野部・肋骨部・縦隔部の統計 的有意差検定で，有意水準 0.05 で検定した結果を示 す (Table 2).

Table 2 は分散分析表で, 列方向に変動成分, 偏 差平方和, 自由度, 平均平方, $\mathrm{F}$ 分布の比, $\mathrm{P}$ 值, 判 定 $(95 \%$ 信頼区間推定で統計的有意差が認められた 場合，SIG と表示)の計算項目が示されている。行方 向は，順次全体 $(\mathrm{TOT})$ ，モダリテイ間 $(\mathrm{T})$ ，試料間 (C)，観察者間 $(\mathrm{R})$ ，モダリティ一試料間 $(\mathrm{TC})$ ，観察

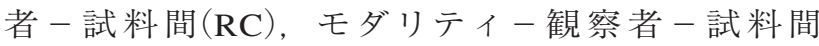
(TRC)において，観察者と試料によって起こる変動 成分の結果が示されている.

表から，Film 画像と LCD 画像のモダリティ $(\mathrm{T})$ 間 では両側 paired $\mathrm{t}$-検定と同様に統計的有意差は認め られなかった。しかし，試料間 $(\mathrm{C})$ とモダリティー試 料間 $(\mathrm{TC})$ で有意差が認められた。なお，ダブルアス タリスク (**)で示されているとおり, 肺野部と肋骨部 では試料間の分散が大きいために観察者一試料間 (RC)での検定は行われていない.

Mann-Whitneyの $U$ 検定の結果を示す (Table 3). 肺野部・肋骨部・縦隔部で求めた $U$ 值は，標本数（観 察者 8 名)が少なく表から得られた $\mathrm{P}<0.05$ の限界值 13 に比し，いずれも統計的有意差は認められなかった。

\section{3. 考 察}

胸部模擬ファントムと肺腺癌ファントムを $\mathrm{CR}$ 装置 で撮影し，異なる表示系の Film 画像と LCD 画像 


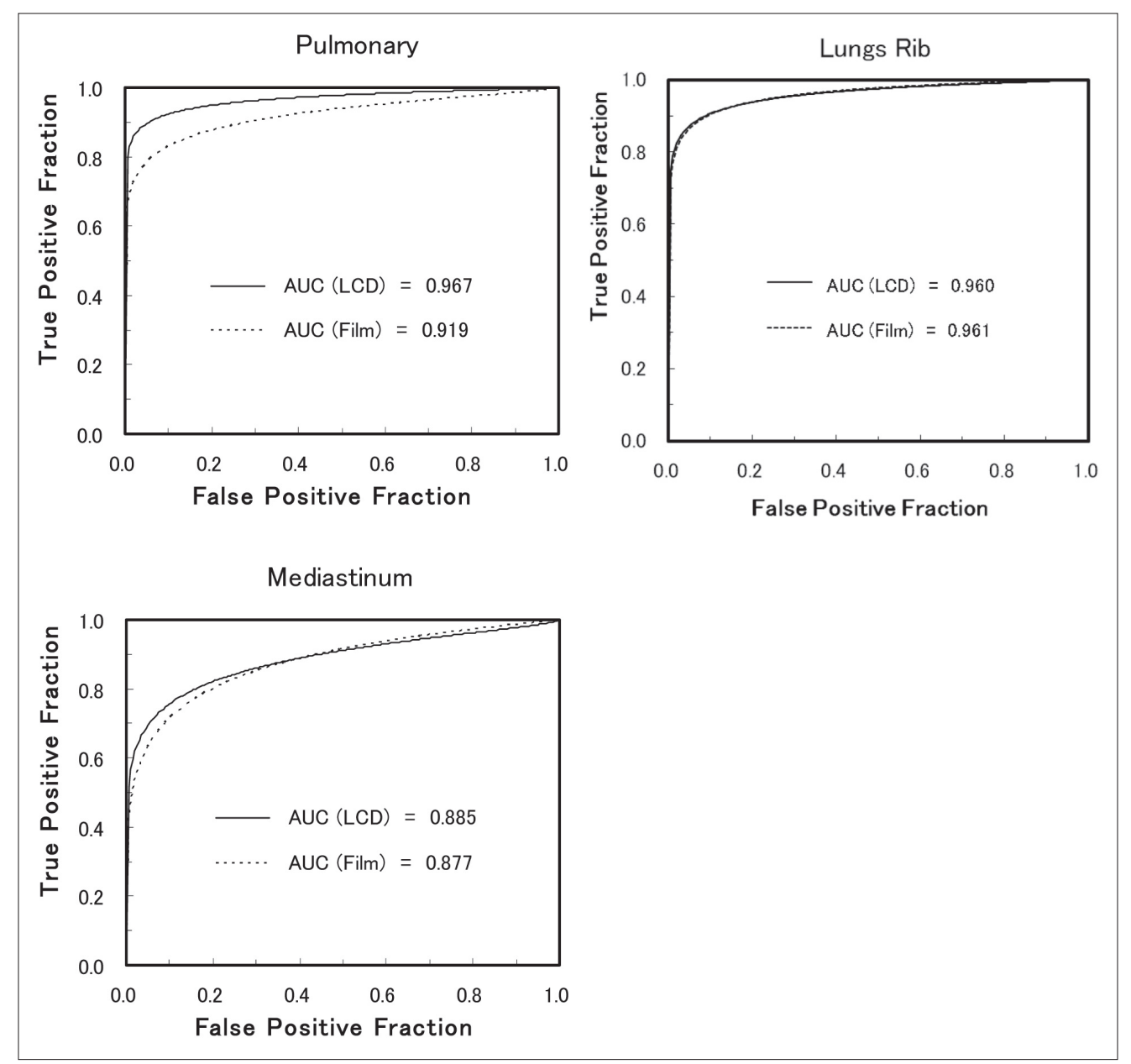

Fig. 5 ROC curves obtained using the average method for the detection of phantoms of small adenocarcinomas using a Regius Model 170 (ST).

(a) Pulmonary.

(b) Lungs Rib.

(c) Mediastinum.

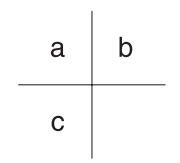

で，検出能の単一指標である AUCで比較評価した.

\section{3-1 ROC 曲線下面積 (AUC)}

今回, 肋骨部での AUC は, Film 画像と LCD 画像 ともに約 $96 \%$ と高い検出能を示した。これはアクリル ファントム $4.0 \mathrm{~cm}$ とアルミニウム $2.0 \mathrm{~cm}$ で作成した 観察試料の濃度が約 1.15 と一様な分布で, 臨床画像の 胁骨陰影と異なり読影が容易であったためと考えられる。

また，管電圧を胸部 X 線撮影に準じた $120 \mathrm{kV}$ で 試料を作成したため, アルミニウムによるX 線減弱 に起因する線質硬化の影響が非常に小さかったと推 定できる.

肋骨部と縦隔部の AUC は, Film 画像と LCD 画像 との差が 0.01 以下と僅差であった。肺野部での AUC の差は, 約 0.05 とわずかに LCD 画像の検出能が高 い值を示した(Fig. 5).

LCD 画像の AUC は, 濃度域と検出能についての 関係は明らかではないが胁骨部と肺野部では同等
Table 1 Results of two-tailed paired t-test of the AUC for film and LCD

\begin{tabular}{lc}
\hline \hline & P value \\
\hline Pulmonary & 0.136 \\
Lungs Rib & 0.585 \\
Mediastinum & 0.867 \\
\hline
\end{tabular}

$\alpha=0.05, \mathrm{~T}$ value 2.145

だった，Film 画像では増感紙ーフィルム系における 胸部 X 線画像の濃度域と detective quantam efficien$\mathrm{cy}(\mathrm{DQE})^{15)}$ の報告と同様に, 肋骨部に対して濃度が 高い肺野部での検出能が低かった。 よって, 肺野部 で Film 画像と LCD 画像とで AUC に差が生じた。 ま た, 観察試料数が杂隹音 15 , 信号 15 の 30 画像と少な いために，観察試料の難易度が異なる 5 種類の肺腺 癌ファントムで生じる変動誤差も関与した可能性が考 えられる。

ROC 曲線の形状は, 負の対角線に対して左に傾い 
Table 2 Test of statistical significance (SIG) of area under the ROC curves (AUC) using the jackknife method. The asterisk shows no examination of the pulmonary fields, lungs, and ribs because the variance between samples is large.

\begin{tabular}{|c|c|c|c|c|c|c|c|}
\hline & Source & $\begin{array}{l}\text { Sums of } \\
\text { squares }\end{array}$ & $\begin{array}{l}\text { Degree of } \\
\text { freedom }\end{array}$ & $\begin{array}{l}\text { Mean } \\
\text { squares }\end{array}$ & F ratios & Prob & Decision \\
\hline \multirow[t]{8}{*}{ Pulmonary } & TOT & 43.5013 & 479 & & & & \\
\hline & $\mathrm{T}$ & 0.0996 & 1 & 0.0996 & 1.6039 & 0.2154 & \\
\hline & $\mathrm{C}$ & 13.7626 & 29 & 0.4746 & 6.4232 & 0.0000 & SIG \\
\hline & $\mathrm{R}$ & 0.5935 & 7 & 0.0848 & 1.1476 & 0.3348 & \\
\hline & TC & 1.8015 & 29 & 0.0621 & 1.0512 & 0.4018 & \\
\hline & TR & 0.2490 & 7 & 0.0356 & 0.6019 & 0.7540 & \\
\hline & $\mathrm{RC}$ & 14.9985 & 203 & 0.0739 & $* *$ & $* *$ & \\
\hline & TRC & 11.9966 & 203 & 0.0591 & & & \\
\hline \multirow[t]{8}{*}{ Lungs rib } & TOT & 35.2798 & 479 & & & & \\
\hline & $\mathrm{T}$ & 0.0330 & 1 & 0.0330 & 0.4408 & 0.5120 & \\
\hline & C & 14.2382 & 29 & 0.4910 & 9.8267 & 0.0000 & SIG \\
\hline & $\mathrm{R}$ & 0.5638 & 7 & 0.0805 & 1.6121 & 0.1336 & \\
\hline & $\mathrm{TC}$ & 2.1709 & 29 & 0.0749 & 1.9229 & 0.0049 & SIG \\
\hline & TR & 0.2283 & 7 & 0.0326 & 0.8378 & 0.5571 & \\
\hline & $\mathrm{RC}$ & 10.1425 & 203 & 0.0500 & $* *$ & $* *$ & \\
\hline & TRC & 7.9030 & 203 & 0.0389 & & & \\
\hline \multirow[t]{8}{*}{ Mediastinum } & TOT & 76.3154 & 479 & & & & \\
\hline & $\mathrm{T}$ & 0.0190 & 1 & 0.0190 & 0.1373 & 0.7113 & \\
\hline & C & 18.9501 & 29 & 0.6535 & 5.1844 & 0.0000 & SIG \\
\hline & $\mathrm{R}$ & 1.5804 & 7 & 0.2258 & 1.7913 & 0.0907 & \\
\hline & $\mathrm{TC}$ & 1.6716 & 29 & 0.0576 & 0.4161 & 0.9968 & \\
\hline & TR & 0.3850 & 7 & 0.0550 & 0.3970 & 0.9034 & \\
\hline & $\mathrm{RC}$ & 25.5863 & 203 & 0.1260 & 0.9098 & 0.7493 & \\
\hline & TRC & 28.1229 & 203 & 0.1385 & & & \\
\hline
\end{tabular}

Table 3 Verification of AUC using the Mann-Whitney $U$ test

\begin{tabular}{lccc}
\hline \hline & \multicolumn{2}{c}{ Sample size } & \multirow{2}{*}{ U value } \\
\cline { 2 - 3 } & LCD & Film & \\
\hline Pulmonary & 8 & 8 & 17 \\
Lungs rib & 8 & 8 & 23 \\
Mediastinum & 8 & 8 & 29 \\
\hline
\end{tabular}

$\alpha=0.05$, Significance point : 13

ている。これは, 濃度分布が一様な杂隹音画像に対 し，観察試料に用いた難易度が異なる 5 種類の肺腺 癌ファントムの検出が難しく，信号画像で判断基準の バラツキが大きくなり, ROC 曲線を両正規確率紙に 転記した直線の傾き $\left(\sigma_{\mathrm{n}} / \sigma_{\mathrm{p}}\right)$ が 1.0 より小さいためと断 定できる (Table 4). ここで, $\sigma_{\mathrm{n}}$ は雑音画像の分散, $\sigma_{\mathrm{p}}$ は信号画像の分散である.

これは, 胸部 X 線画像に比し, 胸部模擬ファント ムに構造物(肺紋理)がないため, 診断結果を母数と して正しく診断した割合を表す指標(正診率)の陽性 予測度 (positive predictive value: PPV)が強調された
Table 4 Gradient of AUC by variance ratio of noise and signal

\begin{tabular}{lccc}
\hline \hline & Pulmonary & Lungs rib & Mediastinum \\
\hline LCD & 0.46 & 0.50 & 0.51 \\
Film & 0.46 & 0.55 & 0.63 \\
\hline
\end{tabular}

ためと考えられる。したがって，本実験の結果を臨床 の胸部 X 線画像へ適用することはできないが，参考 データとして有用と考えられる。

\section{3-2 統計的有意差検定}

両側 paired t-検定, Jackknife 法, Mann-Whitney の $U$ 検定を用いて統計的有意差検定を行った。肺野 部・肋骨部・縦隔部においてすべての検定法で $\mathrm{P}$ 值は 0.05 よりも大きい值を示し (Table 1〜3), 観察試料間 の変動, データの分布型を考慮しても肺腺癌ファント ムの検出能に統計的有意差を認められなかった。し たがって, 肺腺癌ファントムのように病変の信号が低 周波域であるときは，画像表示システムとして Film 画像の読影から LCD 画像の読影に移行が可能であ 
ることが示唆された.

Jackknife 法では肺野部・肋骨部・縦隔部の試料間 (C)において統計的有意差が認められた。この試料間 の有意差は，検出が比較的容易な試料から困難な試 料までの難易度が異なる 5 種類の肺腺癌ファントム

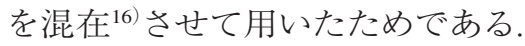

肋骨部ではモダリティー試料間 (TC)でも有意差を 認めた。これは試料が少数で難易度が異なる 5 種類 の肺腺癌ファントムによる変動誤差がAUC の高い肋 骨部でより影響を受けた結果で，観察者一試料間 (RC)の変動誤差と同様 ${ }^{16)}$, この有意差は問題になら ないと考えられる。

ROC 解析では, 観観察者数は 5〜10 名, 観察試料 数は少なくても 30 画像で行うことが求められてい る.しかし，統計的誤差を 2〜3\%にするためにはさ らに画像数を増やす必要があり 150～250 画像 ${ }^{17)}$ で実 験を行うことが推奨されている。よって， ROC 解析 における統計的な取り扱いでは，確信度のデー夕分 布の型を考慮し，確信度の分布を安定させるために 必要なサンプルサイズについての検証が重要で, 課

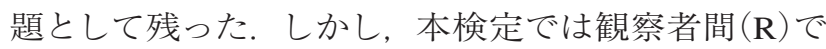
統計的有意差が認められなかった。よって, 観察者 8 名の読影能力に差がなく検定結果に問題はない.

写真濃度值が低い縦隔部は，AUC が小さくなる傾 向がみられた(Fig. 5)。P值は，写真濃度別に比較す ると濃度が低くなるにしたがって増加し，有意差がよ り起こりにくくなったと考えられる.

今回はデータが少なかったので確信度の分布の型 に関わらず検定できるMann-WhitneyのU 検定でも 検証した結果，データの分布型の影響を受けずに統 計的有意差は認められなかった. Mann-Whitneyの $U$ 検定は，母代表值の中央值で比較し，独立した 2 標
本のどちらかが大きければ判定できる。よって，雑音 の確信度と信号の確信度で差があるために統計的有 意差は認められなかったと考えられる。

以上, ROC 解析で観察者と観察試料数が十分に 多いときは，正規分布を背景にしたパラメトリック検 定法で観察者間変動や観察試料間変動も評価できる Jackknife 法が正確な検定を行えると報告 ${ }^{16) さ れ て い ~}$ る. Jackknife 法で検定できるDBM 法は, 本研究の ような確信度の正規性が弱い観察試料を用いたモ夕゙ リティの比較においてもその有用性が確認でき, 頑 健なソフトであることが分かった。しかし，連読確信 度のデー夕分布型が分からない場合は，平均值検定 と同じ結果が得られる7) ノンパラメトリック法の Mann-Whitneyの $U$ 検定も有用な方法と考えられる.

\section{4. 結 語}

肺腺癌ファントムと胸部模擬ファントムで作成した 画像を，ハードコピー(Film)とソフトコピー(LCD)の 異なる画像表示系で ROC 解析を行い, AUCにより 検出能について比較検討した。

肺野部・肋骨部・縦隔部での Film 画像と LCD 画 像の AUC は，パラメトリック法の両側 paired t-検定 と Jackknife 法で統計的有意差を認められず, Film 画像と LCD 画像の検出能は同等であった。 よって, 低周波域に信号成分を有する肺腺癌等の撮影系で は，画像表示システムとして LCD がFilmに代われ ることが示唆された.

\section{謝 辞}

実験に使用した肺腺癌ファントムの資料とファント ム作成に助言いただきました大分県立病院の小野孝 二先生に感謝致します。 


\section{参考文献}

1) Hwang SA, Seo JB, Choi BK, et al. Liquid crystal display monitors and cathoderay tube monitors: acompari- son of observer performance in the detection of small solitary pulmonary nodules. Korean J Radiol 2003; 4(3): 153-156.

2) 池田龍二, 桂川茂彦, 下之坊俊明, 他. 胸部結節状陰影 と間質性肺病変の検出に関する LCD と CRT モニタの比 較。日放技学誌 2006; 62(5): 734-740.

3) MacMahon H, Metz CE, Doi K, et al. Digital chest radiograpy: effect on diagnostic accuracy of hardcopy, conventional video, and reversed gray scale video display formats. Radiology 1988; 168(3): 669-673.

4）伊藤善治，石垣武男，佐久間貞行. CRT 表示における ディジタル X 線像の評価一基礎的及び臨床的検討一。 日 医放会誌 1988; 48: 1024-1031.

5) Dorfman DD, Berbaum KS, Metz CE. Receiver perating characteristic rating analysis: Generalization to the population of readers and patients with the Jackknife method. Invest Radiol 1992; 27(9): 723-731.

6）小野孝二, 赤羽恵一, 羽田道彦, 他. 視覚評価のための 肺腺癌模擬病変ファントムの開発. 日放技学誌 2004 ; 60(9): 1301-1307.

7) 渡邊宗孝, 寺見春惠. ビギナーのための統計学. 東京： 共立出版, 1992.

8）竹吉千市. 胸部撮影法の基礎的研究, 日放技学誌 1975; 31(3): 249-285
9)エックス線写真専門委員会．診断に適した胸部単純 X 線 写真の諸条件、エックス線写真精度管理調査結果報告書 2009．2．全国労働衛生団体連合会，2009：32-34.

10) 奥山武雄. 骨 X 線像の定量的観察についての研究(鉱物 物質含有量の X 線学的測定)。日医放会誌 1965; 25(7): 775-790.

11）白石順二, 山下一也. ROC 評定におる察距離と観察時間 一単純な信号の場合一。 日放技学誌 1991; 47(11): 19371942.

12）祐延良治．LCD モニ夕の性能評価，日放技学近畿部会誌 2005; 11(2): 26-29.

13) National Electrical Manufactures Association 1300 N 17th Street: Digital Imaging and Communications in Medicine (DICOM) Part 14: Grayscale Standard Display Function.

14）門間正彦，佐藤 斉，阿部慎司，他. 医用画像モ二夕に おける階調特性の簡易測定法. 茨城県立医療大学紀要 2007; 12: 59-65.

15）岡田弘治，宇佐美公男，倉又雄一，他．胸部 X 線写真に おける総合的画像解析 I一濃度域にわたる解析一。 日放 技学誌 $1988 ; 44(1): 10-17$.

16）白石順二, 宇都宮あかね. ROC 解析に打ける画像システ ム間の統計的有意差の検定方法一Jackknife 法とその適用 一. 日放技学誌 1997; 53(6): 691-698.

17）山下一也．画像評価法[III]5．信号検出理論による画質評 価. 日放技学誌 1992; 48(12): 2081-2092.

Fig 1 観察実験に用いた肺線癌ファントム ${ }^{6}$

Fig 2 観察に用いた 16 分割の画像

円内に肺線癌ファントムが描写されている。

Fig 3 液晶モニタの GSDF と測定した階調曲線

Fig 4 測定した階調特性と GSDF のコントラスト応答

Fig 5 肺線癌ファントムの X 線画像を用いたアベレージ法による ROC 曲線
(a)肺野部
(b)肋骨部
(c) 縦隔部

Table 1 フィルムと LCD の AUC による両側 5\%の paired t-検定の結果

Table 2 Jackknife 法を用いた AUC の統計的有意差検定

アスタリスクは肺野部と肋骨部では試料間の分散が大きいために検定をしなかったことを示す.

Table 3 AUCによるMann-Whitney $U$ 検定の結果

Table 4 雑音と信号の分散比によるAUC の傾き 